\title{
Chemical Ingredients of Fresh and Dry Wild Mushrooms from Bosnia and Herzegovina
}

\author{
Mirsada Salihović ${ }^{1 *}$, Mirha Pazalja $^{1}$, Melita Huremović ${ }^{2}$, Atifa Ajanović ${ }^{3}$ and Ismet Tahirović ${ }^{4}$ \\ 'Faculty of Pharmacy, University of Sarajevo, Zmaja od Bosne 8, 71000 Sarajevo, \\ Bosnia and Herzegovina; mirsada.salihovic@ffsa.unsa.ba \\ ${ }^{2}$ Faculty of Science, University of Tuzla, Univerzitetska 4, 75000 Tuzla, Bosnia and Herzegovina \\ ${ }^{3}$ Faculty of Veterinary Medicine, University of Sarajevo, Zmaja od Bosne 90, \\ 71000 Sarajevo, Bosnia and Herzegovina \\ ${ }^{4}$ Faculty of Science, University of Sarajevo, Zmaja od Bosne 33, \\ 71000 Sarajevo, Bosnia and Herzegovina
}

\begin{abstract}
Many species of wild mushrooms are used as a delicacy in the diet, but data on their nutritional value and the effects of their storage on nutritional values are rare. The aim of this study was to determine the content of Free Amino Acids (FAAs), total carbohydrates, vitamin C, and total anthocyanins in six wild mushroom species collected in Bosnia and Herzegovina. Results showed that the drying of mushrooms does not have much influence on the presence of essential and non-essential amino acids. Mushrooms are an excellent source of amino acids whether they are fresh or dry. The total carbohydrate content varied between $12.25-62.75 \mathrm{mg} \mathrm{g}^{-1}$ for fresh mushroom extracts and 40.98-167.24 $\mathrm{mg} \mathrm{g}^{-1}$ for dry mushroom extracts. The total carbohydrate content in dry mushrooms is significantly higher than in extracts of fresh mushrooms. The vitamin C content of mushrooms varied between $0.02-1.95 \mathrm{mg} \mathrm{g}^{-1}$ for fresh mushrooms and $0.0-0.63 \mathrm{mg} \mathrm{g}^{-1}$ for dry mushrooms. A lower vitamin C content was found in dry mushrooms, which can be affected by the method of drying mushrooms. The total anthocyanins content varied between 0.39-0.66 $\mathrm{mg} \mathrm{CGE} \mathrm{mL}^{-1}$ for fresh mushroom extracts and 0.10$0.19 \mathrm{mg} \mathrm{CGE} \mathrm{mL}^{-1}$ for dry mushroom extracts. Lower total anthocyanins content was found in dry mushroom extracts, probably due to the destruction of anthocyanins by drying. Our research shows that selected wild edible mushrooms, fresh and dry, have considerable nutritional potential. However, further research is needed on both other nutrients and antinutrients in these mushrooms to support their nutritional dominance.
\end{abstract}

Keywords: Free Amino Acids (FAAs), Total Anthocyanins, Total Carbohydrates, Vitamin C, Wild Mushrooms

\section{Introduction}

Since the early beginnings of human civilization, mushrooms have been a very interesting botanical group, and their edibility and therapeutic abilities attracted even the ancient cultures of the Asians, Greeks, Romans, and Egyptians $^{1,2}$. Increasing people's awareness of healthy foods attracted edible mushroom utilization since they provide important macro and micronutrients $s^{3-5}$. Many species of wild edible mushrooms are rich in essential nutrients such as vitamins, minerals, carbohydrates, proteins, various amino acids, fats, and fiber. Many people consume them as a delicacy, and particularly for their specific aroma and consistency. Mushrooms generally contain many essential nutrients in good quantities ${ }^{6,7}$. Therefore, mushrooms represent a balanced nutrient composition and are considered an attractive and substitute source of high-quality protein with essential and

${ }^{*}$ Author for correspondence 
non-essential amino acids. Due to the content of essential amino acid mushrooms are very useful for a vegetarian diet since they contain some essential amino acids which are found in animal proteins ${ }^{8}$. Also, edible mushrooms contain significant amounts of vitamins such as riboflavin, thiamine, niacin, ascorbic acid, pantothenic acid, and the minerals contained in mushrooms are: iron, manganese, magnesium, zinc, and selenium ${ }^{9,10}$. Carbohydrates are found in large amounts in edible mushrooms, including glycogen, chitin, mannitol, and trehalose. Furthermore, they contain fiber, b-glucans, hemicellulose, and special ingredients. The broad spectrum of carbohydrates in mushrooms ranges from homopolymers to very complex heteropolymers with anti-tumor activity. Certain carbohydrates have been found in various mushrooms that have been shown to have immunomodulatory properties: glucose, fructose, mannose, sucrose, maltose, arabinose, rhamnose, and xylose ${ }^{11}$. Although fruits are known to be the main source of anthocyanins, they are also found in mushrooms. Anthocyanins are a very complex and interesting group due to the great diversity of their presence in nature. They are nutritious bioactive components with a dual significance: firstly, technologically due to their influence on the sensory properties of foods, and secondly biologically due to their numerous health benefits, the most important of which is the cardio protective effect ${ }^{12,13}$. However, there are few studies to evaluate anthocyanins in relation to the antioxidant activity of wild edible mushrooms. One of the studies showed that high amounts of anthocyanins are found in some mushrooms. The high amounts of anthocyanins found in cultivated and wild mushrooms in this study indicate that anthocyanins are important for the conferring of antioxidant activity ${ }^{14}$. Due to the high content of anthocyanins and phenolic compounds but and nutritional values, extracts of many mushrooms are used in the pharmaceutical industry as raw materials for the production of various preparations $s^{15}$.

This paper analyzed wild edible mushrooms, which are commonly used in diets and occur in natural habitats in our areas. Given the limited knowledge of the nutritional values of wild edible mushrooms and the effects of their storage on nutritional values, the aim of this paper is to determine the content of free amino acids, carbohydrates, ascorbic acid, and anthocyanins in fresh and dry selected wild edible mushrooms from Bosnia and Herzegovina.

\section{Experimental}

\subsection{Plant Material (Mushroom Samples)}

Mushroom samples: Lactarius piperatus, Boletus edulis, Craterellus cibarius, Hydnum repandum, Cantharellus cibarius, and Cantharellus tubiformis used for the analysis, were collected in Vlasic ( $44^{\circ} 16^{\prime} 60.00^{\prime \prime} \mathrm{N} ; 17^{\circ} 39^{\prime} 59.99^{\prime \prime}$ E). Mount Vlasic is located in the center of Bosnia and Herzegovina. After the collection, the mushroom samples were delivered to the laboratory within $12 \mathrm{~h}$ and to the drying plant. The mushroom samples were first cleaned of mechanical impurities and damaged parts were removed. A part of the mushrooms was cut into slices of uniform thickness of 5-7 $\mathrm{mm}$ and dried in a universal tunnel dryer (type MTS, Progres Cacak) at $70^{\circ} \mathrm{C}$ for $4-5$ $\mathrm{h}$, and the second part was kept in the fridge at $4^{\circ} \mathrm{C}$ until analysis. Their identification was based on a comparison of their morphological, anatomical, and physiological characteristics with the monographs mentioned in the relevant literature $e^{16,17}$.

\subsection{Chemicals and Reagents}

Ascorbic acid, glucose, bromine, 2,4-dinitrophenylhydrazine (DNPH), acetic acid, sulfuric acid, ethanol, anthrone, potassium chloride, hydrochloric acid 37\%, sodium acetate trihydrate were purchased from SigmaAldrich (St. Louis, USA); meta-phosphoric acid, and $10 \%$ thiourea were purchased from Kemika, Zagreb, Croatia. Amino acid: $L$-valine (Val), L-leucine (Leu), $L$-phenylalanine (Phe), $L$-tryptophan (Trp), $L$-methionine (Met), $L$-arginine (Arg), L-glycine (Gly), $L$-tyrosine (Tyr), $L$-alanine (Ala), and $L$-cysteine (Cys) were purchased from Fluka Chemicals, Switzerland. The chemicals and solvents used are of analytical quality.

\subsection{Preparation Solutions}

Metaphosphoric acid - acetic acid: $8.15 \mathrm{~g}$ of solid metaphosphoric acid was dissolved in a mixture of $20 \mathrm{~mL}$ acetic acid and $220 \mathrm{~mL}$ distilled water in a flask with a volume of $250 \mathrm{~mL}$ and the solution produced was filtered.

2, 4-dinitrophenylhydrazine solution (DNPH): $1 \mathrm{~g}$ DNPH was dissolved in $100 \mathrm{~mL} 4.5 \mathrm{M}$ sulfuric acid.

Anthron: $100 \mathrm{mg}$ anthron was dissolved in a $50 \mathrm{ml}$ flask in $95 \%$ sulfuric acid. 
Standard amino acid solutions: $1 \mathrm{mg} / \mathrm{mL}$ amino acids stock solution is prepared by dissolving $10 \mathrm{mg}$ amino acid in a $10 \mathrm{~mL}$ solution of ethanol.

Standard ascorbic acid solutions: $1 \mathrm{mg} / \mathrm{mL}$ ascorbic acid stock solution is prepared by dissolving $10 \mathrm{mg} \mathrm{AA}$ in a $10 \mathrm{~mL}$ solution of meta-phosphoric acid-acetic acid.

Standard glucose solution: $1 \mathrm{mg} / \mathrm{mL}$ glucose stock solution is prepared by dissolving $100 \mathrm{mg}$ glucose in 100 $\mathrm{mL}$ distilled water.

\subsection{Sample Preparation for Determination of Ascorbic Acid}

The maceration was performed of $2 \mathrm{~g}$ of fresh and dry mushrooms in a mortar with $10 \mathrm{~mL}$ of a solution of meta-phosphoric acid - acetic acid. After maceration, the samples were centrifuged for $20 \mathrm{~min}$. at $4000 \mathrm{rpm}$. The supernatant was decanted and filtered after centrifugation. The filtrate is transferred into a $10 \mathrm{~mL}$ flask and then fills the flask volume with a solution of meta-phosphoric acidacetic acid. Samples should be diluted 10 times before measurement.

\subsection{Sample Preparation for the Determination of Free Amino Acids (FAAs), Total Carbohydrates and Total Anthocyanine}

The fresh and dry edible wild mushrooms $(1 \mathrm{~g})$ were cut into smaller pieces and macerated in a mortar with a pestle, gradually adding $15 \mathrm{~mL}$ of ethanol. The mixture was stirred for about $24 \mathrm{~h}$ at $20-24^{\circ} \mathrm{C}$. After centrifugation, the supernatants were separated by means of a micropipette and evaporated to dryness under reduced pressure at $40^{\circ} \mathrm{C}$. The extracts obtained were stored in glass vials at $4^{\circ} \mathrm{C}$. To determine the total carbohydrates, a solution of fresh and dry mushrooms extract in a concentration of $1 \mathrm{mg} / \mathrm{mL}$ is first prepared and then diluted with distilled water at a ratio of 1:1000.

\subsection{Identification and Quantification of Amino Acids}

Amino acids identification: FAAs in fresh and dry wild mushroom extracts were identified by determining their retention factor Rf, which is compared to the $\mathrm{Rf}$ values of standard amino acid solutions. Ethanolic extracts of fresh and dry mushrooms and amino acid standard were applied to a TLC plate previously coated with silica gel (F254). The mobile phase for the development of chromatogram was: 2-butanol: glacial acetic acid: distilled water (8:2:2). Detection took place at $254 \mathrm{~nm}$, and the Rf values were calculated using the obtained chromatogram ${ }^{18}$.

HPTLC amino acids quantification: For the HPTLC analysis of amino acids, $10 \times 10 \mathrm{~cm} \mathrm{Al}$ plates coated with silica gel 60 F254 were used. Standard amino acid solutions and ethanolic extracts of fresh and dry mushrooms were applied to the $\mathrm{Al}$ plates with a sample applicator (Camag Linomat V - Switzerland). Mobile phase: 2-butanol: glacial acetic acid: water 8: 2: 2 was used and a ninhydrin solution was used to visualize the developed plates. Quantification of FAAs performed by scanning plates at $540 \mathrm{~nm}$ using TLC scanner "Camag" and software "WINCAT"18.

\subsection{Procedure for Total Carbohydrates Determination}

The anthron method was used to determine the total carbohydrates in extracts of fresh and dry wild mushrooms ${ }^{19}$. Extracts of fresh and dry mushrooms (0.5 $\mathrm{mL}$ ) were added to $2 \mathrm{~mL}$. Anthrone solution and heated in a warm water bath for $10 \mathrm{~min}$. When heated, a green color develops, the intensity of which depends on the mass concentration of total carbohydrates. After cooling on ice is performed and the absorption is measured at 630 nm. (spectrophotometer model UV-1280 - Shimadzu). Dilutions of $0.02,0.04,0.06,0.08$, and $0.10 \mathrm{mg} / \mathrm{mL}$ were prepared from glucose stock solution. Repeat the same procedure as when measuring the extracts of dry and fresh mushrooms, except that the diluted glucose solution is added instead of the mushroom extracts.

\subsection{Procedure for Ascorbic Acid Determination}

Extracts of dry and fresh mushrooms $(2 \mathrm{~mL})$ were transferred into $10 \mathrm{~mL}$ vials, then $115 \mu \mathrm{L}$ of $3 \%$ bromine water was added and mixed well. $65 \mu \mathrm{L}$ of $10 \%$ thiourea and $500 \mu \mathrm{L}$ of DNPH solution were added. Solutions obtained were heated at $37^{\circ} \mathrm{C}$ for $3 \mathrm{~h}$. After heating, the solutions were put on ice for $30 \mathrm{~min}$. Chilled 2,5 mL 85\% $\mathrm{H}_{2} \mathrm{SO}_{4}$ was added to the cold solutions and the absorbency was measured at $521.5 \mathrm{~nm}$. The blank was prepared in the same way, except that instead of the sample solution $2 \mathrm{~mL}$ of meta-phosphoric acid-acetic acid solution were 
added $^{20}$. Standard solutions of ascorbic acid 0.005, 0.010, $0.020,0.040,0.080$ and $0.100 \mathrm{mg} / \mathrm{mL}$ were prepared from a stock solution of $1 \mathrm{mg} / \mathrm{mL}$ ascorbic acid by proper dilution. Before the absorption measurement at 521.5 $\mathrm{nm}$ (spectrophotometer model UV-1280 - Shimadzu), samples of standard solutions were prepared in the same way as extracts of dry and fresh mushroom samples.

\subsection{Procedure for Total Anthocyanins Determination}

The method of $\mathrm{pH}$ differential spectrophotometry was used to determine the total anthocyanins in extracts of dry and fresh wild mushroom ${ }^{21,22}$. Two test tubes were prepared to measure one sample. $1 \mathrm{~mL}$ of mushrooms sample solution was pipette into each tube. $2 \mathrm{~mL} \mathrm{pH} 1.0$ buffer was then put into one tube, and $2 \mathrm{~mL} \mathrm{pH} 4.5$ buffers into the other tube. After $20 \mathrm{~min}$., absorptions at $520 \mathrm{~nm}$ and $700 \mathrm{~nm}$ (spectrophotometer model UV-1280 - Shimadzu) were measured with the prepared reaction solutions. Buffer $\mathrm{pH}$ 1.0 and buffer $\mathrm{pH} 4.5$ were used as blank. The method is based on the knowledge that anthocyanins as organic substances are subject to structural changes when the $\mathrm{pH}$ value of the solution changes. At $\mathrm{pH}=1.0$, anthocyanins are colored, and at $\mathrm{pH}=4.5$, they are uncolored, which is measured spectrophotometrically at different wavelengths, and absorptions are read. The proportion of total anthocyanins in the extracts of dry and fresh mushroom is calculated using the absorption difference according to the following equation ${ }^{23}$ :

$$
\mathbf{m g ~ C G E} / \mathbf{g}=\frac{A \times M W \times D F \times 1000}{\varepsilon \times L}
$$

where:

$\mathbf{A}=(\mathrm{A} 520 \mathrm{~nm}-\mathrm{A} 700 \mathrm{~nm}) \mathrm{pH} 1,0-(\mathrm{A} 520 \mathrm{~nm}-$ A700 nm) pH4, 5

MW- molecular weight of cyaniding-3-glucoside

DF- dilution factor,

$\varepsilon$ - molar absorbance

$\mathbf{L}$ - path length

\section{Results}

The content of ethanolic extracts per $1 \mathrm{~g}$ of fresh and dry mushroom samples is shown in Table 1.

The obtained results of HPTLC analysis of FAAs of fresh and dry mushrooms are shown in Table 2.

The results of total carbohydrates, vitamin $\mathrm{C}$, and total anthocyanins of fresh and dry mushroom extracts are shown in Table 3.

Table 1. Content of extract per 1g fresh and dry wild mushroom samples

\begin{tabular}{|l|c|c|}
\hline \multirow{2}{*}{\multicolumn{1}{c|}{ Mushroom species }} & \multicolumn{2}{c|}{ Content $\left(\mathbf{m g ~ g}^{-1}\right) \pm$ SD } \\
\cline { 2 - 3 } & fresh & $d r y$ \\
\hline Lactarius piperatus & $100 \pm 0.98$ & $160 \pm 0.99$ \\
\hline Boletus edulis & $10 \pm 1.51$ & $40 \pm 1.70$ \\
\hline Craterellus cibarius & $70 \pm 0.85$ & $150 \pm 0.98$ \\
\hline Hydnum repandum & $150 \pm 2.20$ & $250 \pm 1.45$ \\
\hline Cantharellus cibarius & $50 \pm 0.69$ & $140 \pm 0.77$ \\
\hline Cantharellus tubiformis & $20 \pm 0.99$ & $60 \pm 0.56$ \\
\hline
\end{tabular}

mean $\pm \mathrm{SD} ; \mathrm{n}=3$

Table 2. Free amino acids content $\left(\mathrm{mg} \mathrm{g}^{-1}\right)$ of fresh and dry wild mushrooms extracts

\begin{tabular}{|c|c|c|c|c|c|c|}
\hline \multirow{2}{*}{$\begin{array}{l}\text { Amino } \\
\text { acids }\end{array}$} & \multicolumn{2}{|c|}{ L. piperatus } & \multicolumn{2}{|c|}{ B. edulis } & \multicolumn{2}{|c|}{ C. cibarius } \\
\hline & fresh & $d r y$ & fresh & $d r y$ & fresh & $d r y$ \\
\hline $\operatorname{Trp}^{*}$ & $0.02 \pm 0.09$ & $0.03 \pm 0.06$ & $0.02 \pm 0.02$ & $0.02 \pm 0.01$ & $0.02 \pm 0.01$ & $n d$ \\
\hline Arg & $34.80 \pm 0.05$ & $23.90 \pm 0.04$ & $3.58 \pm 0.04$ & $2.50 \pm 0.02$ & $1.01 \pm 0.02$ & $0.99 \pm 0.01$ \\
\hline Cys & $2.51 \pm 0.10$ & $4.02 \pm 0.09$ & $13.20 \pm 0.09$ & $n d$ & $1.89 \pm 0.02$ & $3.43 \pm 0.02$ \\
\hline Met $^{*}$ & $0.01 \pm 0.03$ & $n d$ & $0.02 \pm 0.05$ & $1.03 \pm 0.02$ & $0.69 \pm 0.04$ & $1.10 \pm 0.02$ \\
\hline Ala & $1.63 \pm 0.05$ & $2.10 \pm 0.04$ & $4.70 \pm 0.03$ & $2.93 \pm 0.02$ & $6.87 \pm 0.03$ & $10.5 \pm 0.01$ \\
\hline $\mathrm{Val}^{*}$ & $0.18 \pm 0.09$ & $0.11 \pm 0.06$ & $1.66 \pm 0.02$ & $1.08 \pm 0.04$ & $0.23 \pm 0.02$ & $1.58 \pm 0.02$ \\
\hline Gly & $4.92 \pm 0.03$ & $2.90 \pm 0.04$ & $5.12 \pm 0.02$ & $3.21 \pm 0.03$ & $0.72 \pm 0.03$ & $0.51 \pm 0.02$ \\
\hline Leu $^{*}$ & $0.30 \pm 0.05$ & $0.28 \pm 0.03$ & $0.70 \pm 0.03$ & $1.06 \pm 0.02$ & $0.28 \pm 0.04$ & $0.65 \pm 0.04$ \\
\hline Phe* & $0.31 \pm 0.09$ & $0.30 \pm 0.04$ & $0.14 \pm 0.04$ & $1.16 \pm 0.02$ & nd & $0.04 \pm 0.02$ \\
\hline Tyr & $0.14 \pm 0.04$ & $1.15 \pm 0.02$ & nd & nd & $n d$ & $n d$ \\
\hline
\end{tabular}


Table 2 Contd...

\begin{tabular}{|c|c|c|c|c|c|c|}
\hline \multirow{2}{*}{$\begin{array}{c}\text { Amino } \\
\text { acids }\end{array}$} & \multicolumn{2}{|c|}{ H. repandum } & \multicolumn{2}{|c|}{ Cantharellus cibarius } & \multicolumn{2}{|c|}{ C.tubiformis } \\
\hline & fresh & $d r y$ & fresh & $d r y$ & fresh & $d r y$ \\
\hline $\operatorname{Trp}^{*}$ & nd & nd & nd & nd & $0.04 \pm 0.06$ & $0.02 \pm 0.04$ \\
\hline Arg & $8.60 \pm 0.02$ & $7.32 \pm 0.01$ & $10.4 \pm 0.03$ & $9.75 \pm 0.01$ & $4.59 \pm 0.04$ & $5.07 \pm 0.02$ \\
\hline Cys & $2.01 \pm 0.01$ & $3.45 \pm 0.02$ & $0.98 \pm 0.02$ & $1.14 \pm 0.02$ & $2.97 \pm 0.02$ & $1.98 \pm 0.01$ \\
\hline $\operatorname{Met}^{*}$ & nd & nd & $1.10 \pm 0.01$ & $1.31 \pm 0.01$ & nd & $0.01 \pm 0.04$ \\
\hline Ala & $1.91 \pm 0.02$ & $2.73 \pm 0.01$ & $5.81 \pm 0.04$ & $7.09 \pm 0.02$ & $4.01 \pm 0.05$ & $3.66 \pm 0.02$ \\
\hline $\mathrm{Val}^{*}$ & $8.67 \pm 0.02$ & $7.98 \pm 0.02$ & $3.22 \pm 0.02$ & $2.78 \pm 0.02$ & $2.92 \pm 0.04$ & $2.09 \pm 0.04$ \\
\hline Gly & $3.14 \pm 0.01$ & $2.99 \pm 0.03$ & $4.91 \pm 0.02$ & $6.01 \pm 0.04$ & $4.01 \pm 0.03$ & $4.73 \pm 0.03$ \\
\hline $\mathrm{Leu}^{*}$ & $6.01 \pm 0.02$ & $5.21 \pm 0.01$ & $0.91 \pm 0.01$ & $0.99 \pm 0.02$ & $5.09 \pm 0.04$ & $4.99 \pm 0.02$ \\
\hline $\mathrm{Phe}^{*}$ & $0.98 \pm 0.02$ & $1.09 \pm 0.02$ & $1.78 \pm 0.04$ & $2.11 \pm 0.01$ & $2.01 \pm 0.02$ & $1.73 \pm 0.02$ \\
\hline Tyr & $0.47 \pm 0.03$ & $0.58 \pm 0.04$ & $n d$ & $n d$ & $2.97 \pm 0.04$ & $3.01 \pm 0.02$ \\
\hline
\end{tabular}

* - Essential amino acid; $\boldsymbol{n d}$ - not detected; -mean $\pm \mathrm{SD} ; \mathrm{n}=3$

Table 3. Total carbohydrates, vitamin C, and total anthocyanins contents in extracts of fresh and dry wild mushrooms

\begin{tabular}{|c|c|c|c|c|c|c|}
\hline \multirow{2}{*}{$\begin{array}{l}\text { Mushroom } \\
\text { species }\end{array}$} & \multicolumn{2}{|c|}{$\begin{array}{l}\text { Total carbohydrates } \\
\left(\mathrm{mg} \mathrm{g}^{-1}\right)\end{array}$} & \multicolumn{2}{|c|}{$\begin{array}{c}\text { Vitamin C } \\
\left(\mathrm{mg} \mathrm{g}^{-1}\right)\end{array}$} & \multicolumn{2}{|c|}{$\begin{array}{l}\text { Total anthocyanin } \\
\text { mg CGE } \mathbf{~ m L}^{-1}\end{array}$} \\
\hline & fresh & $d r y$ & fresh & $d r y$ & fresh & $d r y$ \\
\hline L. piperatus & $33.0 \pm 0.14$ & $167.24 \pm 0.18$ & $0.22 \pm 0.09$ & $n d$ & $0.46 \pm 0.01$ & $0.19 \pm 0.02$ \\
\hline B. edulis & $24.38 \pm 0.20$ & $40.98 \pm 0.41$ & $0.04 \pm 0.10$ & $n d$ & $0.39 \pm 0.02$ & $0.12 \pm 0.01$ \\
\hline C. cibarius & $12.25 \pm 0.17$ & $58.67 \pm 0.20$ & $1.57 \pm 0.05$ & $0.63 \pm 0.22$ & $0.66 \pm 0.01$ & $0.18 \pm 0.04$ \\
\hline H. repandum & $60.57 \pm 0.20$ & $101.93 \pm 0.14$ & $0.02 \pm 0.02$ & nd & $0.50 \pm 0.04$ & $0.10 \pm 0.02$ \\
\hline $\begin{array}{l}\text { Cantharellus } \\
\text { cibarius }\end{array}$ & $62.75 \pm 0.18$ & $144.38 \pm 0.19$ & $1.95 \pm 0.04$ & $0.52 \pm 0.01$ & $n d$ & $n d$ \\
\hline C. tubiformis & $33.63 \pm 0.22$ & $49.99 \pm 0.15$ & $1.25 \pm 0.02$ & $0.48 \pm 0.01$ & $n d$ & $n d$ \\
\hline
\end{tabular}

mean \pm SD; $\mathrm{n}=3$; $\boldsymbol{n d}$ - not detected

\section{Discussion}

Content of ethanol extracts of fresh and dry wild mushrooms. According to the literature, ethanol is most commonly used in the extraction of various types of mushrooms, whereby the extracts obtained have beneficial properties in terms of composition and content of nutritional values and pharmacologically important compounds ${ }^{23,24}$. Due to the advantage of ethanol over other solvents and its non-toxicity and possible further use of the extracts in the food and pharmaceutical industries, ethanol extraction of selected wild mushrooms was carried out. Hydnum repandum has the highest content of ethanol extract of all analyzed fresh and dry mushrooms and the lowest has Boletus edulis.

\subsection{Amino Acid Compositions}

Qualitative TLC identification confirmed the presence of ten FAAs. The results of HPTLC analysis of FAAs of fresh and dry mushrooms are shown in Table 2. The need for proteins in the human diet actually boils down to the need for essential amino acids. The content of amino acids is one of the most important criteria used to determine the quality of proteins. Proteins that contain all essential amino acids in the proportions required by the body are often classified as high-quality biological proteins ${ }^{25}$. In this study, five essentials, and five non-essential amino acids were analyzed in six species of wild mushrooms.

Non-essential acids such as arginine, alanine, and glycine were detected in all six types of fresh and dry 
mushrooms. These non-essential acids are known to improve the immune system. Val and Leu, essential amino acids, promote mental strength ${ }^{26}$. These amino acids have been found in all fresh and dry mushrooms. A total of 10 FAAs were found in fresh L. piperatus and dry C. tubiformis. Met, one of the essential amino acids for humans, was not detected in dry L. piperatus and fresh C. tubiformis, and fresh and dry H. repandum. Cys, a non-essential acid, antioxidant, helps the body protect against radiation and pollution, inhibits aging, helps in protein synthesis and cellular changes ${ }^{27,28}$. This amino acid has not only been found in dry B. edulis. Tyr, a nonessential acid, helps to overcome depression, improves memory, increases mental alertness, promotes healthy thyroid, adrenal and pituitary function ${ }^{29}$. Tyr has been found in fresh and dried L. piperatus, $H$. repandum and C. tubiformis. Phe, an essential amino acid produced by norepinephrine, acts as an antidepressant and improves memory. The highest content of this amino acid is found in dry C. tubiformis and not found, only in fresh C. cibarius. Trp, an essential amino acid, promotes relaxation, helps with insomnia, and reduces anxiety and depression. This amino acid has not been found in dry C. cibarius, fresh and dry H. repandum and Cantharellus cibarius. Our results for B. edulis, C. cibarius, and H. repandum are similar to those reported by Bakir et al. (2018) ${ }^{29}$, for L. piperatus and Cantharellus cibarius Salihović et al. (2019) ${ }^{30}$. Based on the concentrations of FAAs determined by HPTLC, it can be concluded that the method of fungal drying mentioned does not have much influence on the presence of essential and non-essential amino acids.

\subsection{Total Carbohydrates}

Edible mushrooms have a typical flavor, which comes from the presence of non-volatile constituents, including soluble carbohydrates and FAAs ${ }^{31,32}$. The total soluble carbohydrate content of fresh and dry mushroom extracts was determined using the Anthrone method. Total carbohydrate determination is based on the reaction of carbohydrates from samples with anthrone reagent by boiling in an acidic medium, which leads to the hydrolysis of complex carbohydrates into glucose, resulting in a green-blue color complex ${ }^{33,34}$. After cooling, the absorption is measured spectrophotometrically at 630 $\mathrm{nm}$. The standard linear calibration curve was executed to obtain the linear range of analysis of dry and fresh mushroom extracts, the correlation factor for glucose was accepted value $\left(\mathrm{R}^{2}=0.9988\right)$ and the standard calibration curve was linear over the range of $0.02-0.10 \mathrm{mg} / \mathrm{mL}$ with the equation $(\mathrm{y}=7.35 \mathrm{x}-0.0154)$.

The results of the total carbohydrates of extracts fresh and dry wild mushrooms are expressed in mg of total carbohydrates per gram of fresh and dry mass of the sample and are shown in Table 3 and Figure 1. Results show that the total carbohydrate content of mushrooms varied between 12.25-62.75 $\mathrm{mg} \mathrm{g}^{-1}$ for extracts of fresh mushrooms and 40.98-167.24 $\mathrm{mg} \mathrm{g}^{-1}$ for extracts of dry mushrooms. The highest total carbohydrates are found in Cantharellus cibarius and the lowest in C. cibarius. The total carbohydrate content of mushrooms can be affected by some factors such as genetic factors, the progress phase of the fruitful body, and the environment ${ }^{35,36}$. Our results for the total carbohydrate content were consistent with the results of Beluhan and Ranogajec $(2011)^{37}$, but were lower than those of Turfan et al. $(2018)^{36}$ for some edible mushrooms. The content of total carbohydrates in mushrooms can deliver to their sweet flavor. Thus, the relatively high sugar content in edible mushrooms is a helpful feature. Our results showed that the total carbohydrate content in dry mushrooms is significantly higher than in extracts of fresh mushrooms, which corresponds to the available literature. Studies have shown that the carbohydrate content is between $35 \%$ and $70 \%$ of the dry matter, although there are differences between different types of mushrooms. Thermal treatment of mushrooms removes water and concentrates nutrients such as carbohydrates ${ }^{38,39}$.

\subsection{Ascorbic Acid (vitamin C)}

For the quantitative analysis of vitamin $\mathrm{C}$ in fresh and dry wild mushrooms, UV-Vis spectrophotometry was

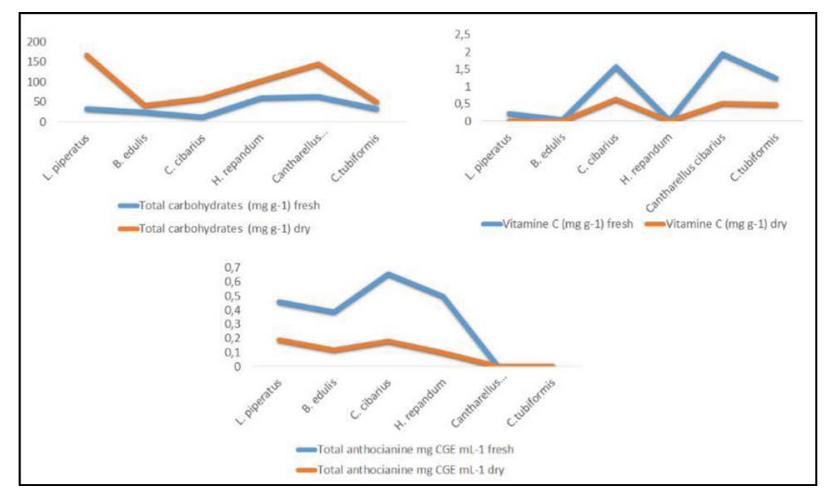

Figure 1. Content of total carbohydrates, vitamin C, and total anthocyanins of fresh and dry mushrooms. 
chosen. Vitamin $\mathrm{C}$ reacts in the sample with the acidic $\mathrm{DNPH}$, whereby it is oxidized to dehydroascorbic acid in the presence of bromine water. Subsequently, $L$-dehydroascorbic acid reacts with DNPH to form osazone, which, treated with $85 \% \mathrm{H}_{2} \mathrm{SO}_{4}$, gives the solution a red color. After cooling, the absorption is measured at $521.5 \mathrm{~nm}$. The ascorbic acid content was calculated based on the calibration curve of the authentic $L$-ascorbic acid $(0.05-0.10 \mathrm{mg} / \mathrm{mL} ; \mathrm{y}=33.051 \mathrm{x}+0.4343$; $\mathrm{R} 2=0.9851)$.

The results for vitamin $\mathrm{C}$ of fresh and dry wild mushrooms were expressed in mg vitamin $\mathrm{C}$ per gram of fresh and dry wild mushrooms and are shown in Table 3 and Figure 1. Results show that the vitamin $\mathrm{C}$ content of mushrooms varied between $0.02-1.95 \mathrm{mg} \mathrm{g}^{-1}$ for fresh mushrooms and $0.0-0.63 \mathrm{mg} \mathrm{g}^{-1}$ for dry mushrooms. The highest vitamin $\mathrm{C}$ content was found in Cantharellus cibarius and the lowest in $H$. repandum. It is known that Chanterelle is a health-promoting nutrient with a high content of vitamins B and C, contains a large number of carbohydrates and proteins, and has a low content of fats, phenolic compounds, and organic acids ${ }^{40,41}$ which corresponds to our results. The data obtained indicate that lower vitamin $\mathrm{C}$ content has been found in dry mushrooms, which is to be expected as the vitamin $\mathrm{C}$ content can also be influenced by the drying method ${ }^{42}$. Oxidation and degradation of vitamin $\mathrm{C}$ are stimulated by many factors such as the influence of light, elevated temperature, enzymes, heavy metals, and alkaline media $^{43,44}$. Our results for vitamin C content were consistent with the results reported by Ferreire, et al. $(2009)^{45}$, but were higher than those reported by Ozen et al. $(2011)^{46}$ for some edible mushrooms.

\subsection{Total Anthocyanins}

The differential $\mathrm{pH}$ method was used to determine the total anthocyanin concentration, which is based on the change in anthocyanin color ${ }^{21}$. Therefore, the method is based on the knowledge that a change in the $\mathrm{pH}$ value causes a structural change in the anthocyanins. At $\mathrm{pH}=1.0$, anthocyanins are stained and at $\mathrm{pH}=4.5$, they are unstained. The proportion of total anthocyanins in the sample is calculated using the difference in absorptions according to the above formula. Results for total anthocyanins for fresh and dry wild mushroom extracts were expressed as equivalent to cyanidin-3-glucoside (mg CGE $\mathrm{mL}^{-1}$ ) of fresh and dry wild mushrooms and are presented in Table
3 and Figure 1. The results show that the total anthocyanins content in mushrooms varied between 0.39-0.66 mg CGE $\mathrm{mL}^{-1}$ for fresh mushroom extracts and 0.10-0.19 mg CGE $\mathrm{mL}^{-1}$ for dry mushroom extracts. In Cantharellus cibarius and C. tubiformis total anthocyanins were not found. The highest total anthocyanins content was found in C. cibarius and the lowest in H. repandum. Our results for the total anthocyanins content were consistent with those reported by Ozen et al. (2011) for some mushroom species $^{46}$. Dry mushroom extracts have significantly lower total anthocyanins content, probably due to their drying destruction ${ }^{47}$. Studies have shown that a significant amount of anthocyanin is lost in the heat treatment of some fruits and foods ${ }^{48}$. In addition to heat and many other factors such as light, temperature, storage and tillage are also responsible for the degradation of anthocyanins ${ }^{49}$. Several factors can influence the composition of the mushrooms, including harvest time, mushroom species, environmental factors, and analysis methods $\mathrm{s}^{50,51}$.

\section{Conclusion}

We have presented here amino acid compositions, the content of total carbohydrates, vitamin $\mathrm{C}$, and total anthocyanins in the ethanol extracts of fresh and dry edible wild mushrooms, which are widely used in Bosnia and Herzegovina. Results show that fresh and dry analyzed mushrooms contain significant amounts of essential and non-essential amino acids. Our results show that the extracts of all six fresh and dry mushrooms have a significant amount of total carbohydrates and vitamin C, but anthocyanins, not only found in Cantharellus cibarius and C. tubiformis. Vitamin C content not found in extracts of dry L. piperatus, B. edulis, and H. repandum. Results of this study show that selected wild mushrooms, both fresh and dry, have considerable nutritional potential. By consuming these fresh or dry wild mushrooms, the recommended daily intake of most nutrients can be achieved. Knowledge of the nutritional and biologically active properties of wild edible mushrooms increases their consumption. However, knowledge of anti-nutrients and toxicity factors in wild edible mushrooms is also necessary to support their predominance in the diet.

\section{Acknowledgements}

This research was supported by the Federal Ministry of Education and Science in Bosnia and Herzegovina, and 
was carried out within the framework of the project "Chemical composition and an antioxidative potential of wild edible mushrooms from Bosnia and Herzegovina" (Grant no. 0101-8183-3/17, dated 01. 12.2017).

\section{References}

1. Wu F, Zhou LW, Yang ZL, Bau T, Li TH, Dai YC. Resource diversity of Chinese macrofungi: Edible, medicinal and poisonous species. Fungal Diversity, 2019; 98(1): 1-76. https:// doi.org/10.1007/s13225-019-00432-7.

2. Gründemann C, Reinhardt JK, Lindequist U. European medicinal mushrooms: Do they have potential for modern medicine?-An update. Phytomedicine, 2020; 66:153131. https://doi.org/10.1016/j.phymed.2019.153131. PMid:31790898.

3. Valverde ME, Hernández-Pérez T, Paredes-López O. Edible mushrooms: Improving human health and promoting quality life. International Journal of Microbiology, 2015. https://doi.org/10.1155/2015/376387. PMid:25685150 PMCid:PMC4320875.

4. Philip D. Biosynthesis of Au, Ag and Au-Ag nanoparticles using edible mushroom extract. Spectrochimica Acta Part A: Molecular and Biomolecular Spectroscopy, 2009, 73.2: 374-381. https://doi.org/10.1016/j.saa.2009.02.037. PMid:19324587.

5. Martinez-Medina GA, Chávez-González ML, Verma DK., Prado-Barragán LA., Martínez-Hernández JL., Flores-Gallegos, A. C., et al. Bio-funcional components in mushrooms, a health opportunity: Ergothionine and huitlacohe as recent trends. Journal of Functional Foods. 2021; 77:104326. https://doi.org/10.1016/j.jff.2020.104326.

6. Ouzouni PK, Petridis D, Koller, WD, Riganakos KA. Nutritional value and metal content of wild edible mushrooms collected from West Macedonia and Epirus, Greece. Food Chemistry. 2009; 115(4):1575-1580. https://doi. org/10.1016/j.foodchem.2009.02.014.

7. Kalač P. A review of chemical composition and nutritional value of wild-growing and cultivated mushrooms. Journal of the Science of Food and Agriculture. 2013; 93(2):209218. https://doi.org/10.1002/jsfa.5960. PMid:23172575.

8. Bach F, Helm CV, Bellettini MB, Maciel GM, Haminiuk CWI. Edible mushrooms: A potential source of essential amino acids, glucans and minerals. International Journal of Food Science and Technology. 2017; 52(11):2382-2392. https://doi.org/10.1111/ijfs.13522.

9. Reis FS, Barros L, Martins A, Ferreira IC. Chemical composition and nutritional value of the most widely appreciated cultivated mushrooms: An inter-species comparative study. Food and Chemical Toxicology. 2012; 50(2):191-197. https://doi.org/10.1016/j.fct.2011.10.056. PMid:22056333.
10. Agarwal S, Fulgoni III VL. Nutritional impact of adding a serving of mushrooms to USDA Food Patterns-a dietary modeling analysis. Food and Nutrition Research. 2021; 65. https://doi.org/10.29219/fnr.v65.5618. PMid:33613153 PMCid:PMC7869438.

11. Rosa GB, Sganzerla WG, Ferreira ALA, Xavier LO, Veloso NC, da Silva J. et al. Investigation of nutritional composition, antioxidant compounds, and antimicrobial activity of wild culinary-medicinal mushrooms boletus edulis and lactarius deliciosus (Agaricomycetes) from Brazil. International Journal of Medicinal Mushrooms. 2020; 22(10). https:// doi.org/10.1615/IntJMedMushrooms.2020036347. PMid: 33426823.

12. Liu Y, Tikunov Y, Schouten RE, Marcelis LF, Visser RG, Bovy A. Anthocyanin biosynthesis and degradation mechanisms in Solanaceous vegetables: A review. Frontiers in Chemistry. 2018; 6:52. https://doi.org/10.3389/ fchem.2018.00052. PMid:29594099 PMCid:PMC5855062.

13. Ozen T, Kizil D, Yenigun S, Cesur H, Turkekul I. Evaluation of bioactivities, phenolic and metal content of ten wild edible mushrooms from western Black Sea region of Turkey. International Journal of Medicinal Mushrooms. 2019; 21(10). https://doi.org/10.1615/ IntJMedMushrooms.2019031927. PMid:32450035.

14. Tajalli F, Malekzadeh K, Soltanian H, Janpoor J, Rezaeian S, Pourianfar HR. Antioxidant capacity of several Iranian, wild and cultivated strains of the button mushroom. Brazilian Journal of Microbiology. 2015; 46(3):769-776. https://doi. org/10.1590/s1517-838246320140180. PMid:26413059 PMCid:PMC4568870.

15. Vamanu E, Nita S. Antioxidant capacity and the correlation with major phenolic compounds, anthocyanin, and tocopherol content in various extracts from the wild edible Boletus edulis mushroom. BioMed research international. 2012; 2013:1-11. https://doi.org/10.1155/2013/313905. PMid:23509707 PMCid:PMC3591155.

16. Moser M. In: Keys to Agarics and Boleti (Polyporales, Boletales, Agaricales, Russulales) Kibby, G, editor. London: Roger Phillips; 1983. p. 1-535.

17. Uzelac B. Gljive Srbije i Zapadnog Balkana. Beograd: BGV Logik; 2009.

18. Harborne JB. Methods of plant analysis. In: Phytochemical Methods, Springer, Dordrecht; 1984. p. 1-36. https://doi. org/10.1007/978-94-009-5570-7_1.

19. John A, Barnett G, Miller TB. The determination of soluble carbohydrate in dried samples of grass silage by the anthrone method. Journal of the Science of Food and Agriculture. 1950; 1(11):336-339. https://doi.org/10.1002/ jsfa.2740011106.

20. Rahman MM, Khan MMR, Hosain MM. Analysis of vitamin $\mathrm{C}$ (ascorbic acid) contents in various fruits and 
vegetables by UV-spectrophotometry. Bangladesh Journal of Scientific and Industrial Research. 2007; 42(4):417-424. https://doi.org/10.3329/bjsir.v42i4.749.

21. Lee J, Durst RW, Wrolstad RE, Eisele T, Giusti MM, Hach J, et al. Determination of total monomeric anthocyanin pigment content of fruit juices, beverages, natural colorants, and wines by the $\mathrm{pH}$ differential method: Collaborative study. Journal of AOAC international. 2005; 88(5):1269-1278. https://doi.org/10.1093/jaoac/88.5.1269. PMid:16385975.

22. Espinosa M. Spectrophotometric determination of anthocyanin content in six common vegetables. Present to the college of arts and sciences central Philippine university: Thesis; 2014. p. 6-18.

23. Hu D, Chen W, Li X, Yue T, Zhang Z, Feng Z, ... Li L. Ultraviolet irradiation increased the concentration of vitamin D2 and decreased the concentration of ergosterol in shiitake mushroom (lentinus edodes) and oyster mushroom (Pleurotus ostreatus) powder in ethanol suspension. ACS omega. 2020; 5(13):7361-7368. https://doi.org/10.1021/ acsomega.9b04321. PMid:32280877 PMCid:PMC7144143.

24. Türkoğlu A, Duru ME, Mercan N. Antioxidant and antimicrobial activity of Russula delica Fr: An Edidle Wild Mushroom. 2007. https://doi.org/10.12973/ejac/78055.

25. Mota C, Santos M, Mauro R, Samman N, Matos AS, Torres D, Castanheira I. Protein content and amino acids profile of pseudocereals. Food Chemistry. 2016; 193:55-61. https:// doi.org/10.1016/j.foodchem.2014.11.043. PMid:26433287.

26. Le Plénier S, Walrand S, Noirt R, Cynober L, Moinard C. Effects of leucine and citrulline versus non-essential amino acids on muscle protein synthesis in fasted rat: A common activation pathway?. Amino Acids. 2012; 43(3):11711178. https://doi.org/10.1007/s00726-011-1172-z. PMid:22160257.

27. Scott TA. Biochemie. Ein lernprogramm: By P. Karlson. Pp. 510. A volume in the Thieme Lernprogramm series published by Georg Thieme Verlag, Stuttgart, 1977. Paperback. DM34. (In German). 1977. https://doi.org/10.1016/03074412(77)90079-6.

28. Heger J. Essential to non-essential amino acid ratios. Amino Acids in Animal Nutrition. 2003; 103:204. https:// doi.org/10.1079/9780851996547.0103.

29. Kan Bakır T, Boufars M, Karadeniz M, Ünal S. Amino acid composition and antioxidant properties of five edible mushroom species from Kastamonu, Turkey. African Journal of Traditional, Complementary and Alternative Medicines. 2018; 15(2):80-87. https://doi.org/10.21010/ajtcamv15i2.10.

30. Salihović M, Šapčanin A, Pehlić E, Uzunović A, ŠpirtovićHalilović S, Huremović M. Amino Acids Composition and Antioxidant Activity of Selected Mushrooms from Bosnia and Herzegovina. Kemija u Industriji. 2019; 68. https://doi. org/10.15255/kui.2018.034.

31. Yang J, Zhang J, Wang Z, Zhu Q, Wang W. Remobilization of carbon reserves in response to water deficit during grain filling of rice. Field Crops Research. 2001; 71(1):47-55. https://doi.org/10.1016/s0378-4290(01)00147-2.

32. Ayaz FA, Torun H, Özel A, Col M, Duran C, Sesli E, et al. Nutritional value of some wild edible mushrooms from the Black Sea region (Turkey). Turkish Journal of Biochemistry/Turk Biyokimya Dergisi. 2011; 36(4). https:// doi.org/10.4236/fns.2011.22007.

33. Loewus FA. Improvement in anthrone method for determination of carbohydrates. Analytical Chemistry. 1952; 24(1):219-219. https://doi.org/10.1021/ac60061a050.

34. Merdivan S, Bettin P, Preisitsch M, Lindequist U. Quality control of medicinal mushrooms: Comparison of different methods for the quantification of polysaccharides/ $\beta$-Glucans. Planta Medica. 2014; 80(16):P1N22. https://doi. org/10.1055/s-0034-1394612.

35. Wang XM, Zhang J, Wu LH, Zhao Y L, Li T, Li JQ, et al. A mini-review of chemical composition and nutritional value of edible wild-grown mushroom from China. Food Chemistry. 2014; 151:279-285. https://doi.org/10.1016/j. foodchem.2013.11.062. PMid:24423533.

36. Turfan N, Pekşen A, Kibar B, Ünal S. Determination of nutritional and bioactive properties in some selected wild growing and cultivated mushrooms from Turkey. Acta. Sci. Pol. Hortorum. Cultus. 2018; 17(3):57-72. https://doi. org/10.24326/asphc.2018.3.6.

37. Beluhan S, Ranogajec A. Chemical composition and non-volatile components of Croatian wild edible mushrooms. Food Chemistry. 2011; 124(3):1076-1082. https:// doi.org/10.1016/j.foodchem.2010.07.081.

38. Mau JL, Lin HC, Chen CC. Non-volatile components of several medicinal mushrooms. Food Research International. 2001; 34(6):521-526. https://doi.org/10.1016/S09639969(01)00067-9.

39. Cheung PC. Mini-review on edible mushrooms as source of dietary fiber: preparation and health benefits. Food Science and Human Wellness, 2013: 2(3-4):162-166. https://doi. org/10.1016/j.fshw.2013.08.001.

40. Watanabe F, Yabuta Y, Bito T, Teng F. Vitamin B12containing plant food sources for vegetarians. Nutrients. 2014; 6(5):1861-1873. https://doi.org/10.3390/nu6051861. PMid:24803097 PMCid:PMC4042564.

41. Vlasenko V, Turmunkh D, Ochirbat E, Budsuren D, Nyamsuren K, Samiya J, et al. Medicinal potential of extracts from the chanterelle mushroom, Cantharellus cibarius (Review) and prospects for studying its strains from differs plant communities of ultracontinental regions of the Asia. 
In: BIO Web of Conferences. EDP Sciences. 2019; 00039. https://doi.org/10.1051/bioconf/20191600039.

42. Patras A, Brunton NP, O’Donnell C, Tiwari BK. Effect of thermal processing on anthocyanin stability in foods; mechanisms and kinetics of degradation. Trends in Food Science and Technology. 2010; 21(1):3-11. https://doi. org/10.1016/j.tifs.2009.07.004.

43. Linster CL, Van Schaftingen E. Vitamin C. The FEBS Journal. 2007; 274(1):1-22. https://doi.org/10.1111/j.17424658.2006.05607.x PMid:17222174.

44. Ahmed N, Singh J, Chauhan H, Anjum PGA, Kour H. Different drying methods: Their applications and recent advances. International Journal of Food Nutrition and Safety. 2013; 4(1):34-42.

45. Ferreira IC, Barros L, Abreu, R. Antioxidants in wild mushrooms. Current Medicinal Chemistry. 2009; 16(12):1543-1560. https://doi.org/10.2174/09298670978790 9587. PMid:19355906.

46. Ozen T, Darcan C, Aktop O, Turkekul I. Screening of antioxidant, antimicrobial activities and chemical contents of edible mushrooms wildly grown in the Black Sea region of Turkey. Combinatorial Chemistry and High Throughput Screening. 2011; 14(2):72-84. https://doi. org/10.2174/138620711794474079. PMid:20958253.

47. Tulio AZ, Chanon AM, Janakiraman N, Ozgen M, Stoner GD, Reese RN, et al. (188) Effects of Storage Temperatures on the Antioxidant Capacity and Anthocyanin Contents of Black Raspberries. Hort. Science. 2006; 41(4):1043A-1043. https://doi.org/10.21273/HORTSCI.41.4.1043A.

48. Alasalvar C, Al-Farsi M, Quantick PC, Shahidi F, Wiktorowicz R. Effect of chill storage and modified atmosphere packaging (MAP) on antioxidant activity, anthocyanins, carotenoids, phenolics and sensory quality of ready-to-eat shredded orange and purple carrots. Food Chemistry. 2005; 89(1):69-76. https://doi.org/10.1016/j. foodchem.2004.02.013.

49. Ferreira D, Guyot S, Marnet N, Delgadillo I, Renard, CM, Coimbra M. A Composition of phenolic compounds in a Portuguese pear (Pyrus communis L. var. S. Bartolomeu) and changes after sun-drying. Journal of Agricultural and Food Chemistry. 2002; 50(16):4537-4544. https://doi. org/10.1021/jf020251m. PMid:12137473.

50. Manzi P, Aguzzi A, Pizzoferrato L. Nutritional value of mushrooms widely consumed in Italy. Food Chemistry. 2001; 73(3):321-325. https://doi.org/10.1016/s03088146(00)00304-6.

51. Nakalembe I, Kabasa JD, Olila D. Comparative nutrient composition of selected wild edible mushrooms from two agro-ecological zones, Uganda. Springerplus. 2015; 4(1):1-15. https://doi.org/10.1186/s40064-015-1188-z. PMid:26306295 PMCid:PMC4542863. 